\title{
Avaliação de posturas para antropometria digital considerando tempo, conforto e qualidade da malha obtida
}

\author{
Assessment of 3D scanning postures for digital anthropometry considering \\ time, comfort and mesh quality obtained
}

\author{
SIERRA, Isabella de S. \\ Universidade Federal do Paraná, Mestre \\ isa.dss@gmail.com \\ BARBOSA, Matheus C. \\ Universidade Federal do Paraná, Graduação \\ cbarbosa.math@gmail.com \\ ROCHA, Bruno \\ Universidade Federal do Paraná, Graduação \\ brunogr96@gmail.com \\ OKIMOTO, Maria Lúcia L. R. \\ Universidade Federal do Paraná, Doutora \\ lucia.demec@ufpr.br
}

\section{RESUMO}

Ao realizar estudos antropométricos digitais em larga escala, além da seleção dos equipamentos, os pesquisadores devem considerar a participação do usuário e o seu próprio trabalho de pós-processamento. Tomou-se como hipótese que ao usar scanners de baixo custo, as principais influências na qualidade da malha são as posturas adotadas e o tempo de varredura, o que afeta a capacidade de manter a postura. Para testar a hipótese, desenvolveu-se um experimento para determinar as melhores posturas, considerando as normas, limitações do equipamento, qualidade da malha obtida, tempo necessário para realizar as digitalizações, análises ergonômicas da postura, conforto dos participantes e nosso hardware de digitalização. Em suma, 16 participantes assinaram acordos de consentimento e foram escaneados três vezes, uma em cada postura, em ordem aleatória, declarando seu nível de conforto no final de cada uma. A plataforma de digitalização utilizada funciona com 3 Kinect 360 . Em seguida, as malhas foram reparadas e classificadas. A postura selecionada foi a que proporcionou a melhor qualidade de malha e foi considerada a mais confortável para os participantes. Encontrou-se que as posturas adotadas tiveram mais influência na qualidade da malha, do que o tempo ou o número de voltas para a digitalização.

Digitalização corporal 3D, antropometria digital, ergonomia, postura, conforto 


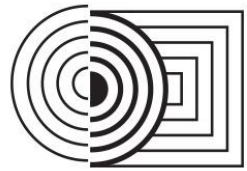

\section{$17^{\circ}$ ERGODESIGN \& USIHC 2019 \\ PUC-Rio, 11 a 13 de dezembro \\ Rio de Janeiro, RJ, Brasil}

$17^{\circ}$ Ergodesign - Congresso Internacional de Ergonomia e Usabilidade de Interfaces Humano Tecnológica: Produto, Informações Ambientes Construídos e Transporte

$17^{\circ}$ USIHC - Congresso Internacional de Ergonomia e Usabilidade de Interfaces Humano Computador

\begin{abstract}
In performing large-scale digital anthropometric studies, besides the choices of equipment, the researchers must consider user participation and also their post-processing work. We hypothesized that in using lowcost scanners, the principal influences on the quality of the mesh are the postures adopted and the scanning time which affects the capability of maintaining the posture. To test our hypothesis, we devised an experiment to determine the best postures, considering the norms, limitations of the equipment, quality of the mesh obtained, scanning time, posture's ergonomic analyses, participant comfort and our scanning hardware. In short, 16 participants signed consent agreements and were scanned three times, one in each posture in a random order answering a comfort scale level at the end of each. The scanning platform used works with 3 Kinect 360. Then, the meshes were repaired and graded. We were able to choose the best posture which was the one that gave the best mesh quality and that was also the most comfortable for the participants so they could hold it for more time. We discovered that the postures adopted had more influence on the quality of the mesh, then the time and the number of turns to do the scanning.
\end{abstract}

$3 D$ body scanning, digital anthropometry, ergonomics, posture, comfort

\title{
1. INTRODUCTION
}

In performing large-scale digital anthropometric studies, using 3D scanning, besides the choices of equipment (KOUCHI, 2012) and accompanying software, the researchers must consider the user participation (SCHWARZ-MUELLER; MARSHALL; SUMMERSKILL, 2018; SILVA; SALVALAIO; KINDLEIN, 2010) and also their own post-processing work (HEYMSFIELD et al., 2018; CUI; STRICKER, 2011). So, we can consider that in the scanning process the participants influence directly the quality of the mesh obtained and that the quality of the mesh accounts for most of the post-processing time and quality of the measurements taken.

This is even more present when considering the use of low-cost hardware such as Kinect, because of its time (BRAGANÇA et al., 2017) and quality limitations (GUIDI; GONIZZI; MICOLI, 2016). Even though the Kinect scanner is a useful choice for performing digital anthropometry, there are still numerous limitations to the equipment. Especially time constraints are relevant because when using only one Kinect, researchers achieve a scanning time between 30 seconds to three minutes (BRENDLER et al., 2016; COSTA et al., 2015; GARSTHAGEN, 2014). Some of these limitations might be mitigated when using more than one Kinect at a time, so to cover more body surface area and ultimately take less time scanning (PARK; REED, 2014). Nevertheless, when adding more Kinects to the study, other concerns arise such as the alignment of the meshes (HIRSHBERG et al., 2011), calibration of the equipment (HEYMSFIELD et al., 2018; KOUCHI, 2012) and structural support (SCHWARZ-MUELLER; MARSHALL; SUMMERSKILL, 2018) to hold all the equipment in fixed positions or moving together. In previous work, we developed a scanning platform that was used in this study to attempt to solve some of the sensors positioning and moving together issues.

As for the quality, it is important to consider what will be the ultimate usage of the digital anthropometry, because when modeling clothes and other consumer products some sizing discrepancies might be acceptable but not when considering medical applications

(VERWULGEN et al., 2018; GUIDI; GONIZZI; MICOLI, 2016). Conflicting results have been arising concerning the quality obtained with the Kinect, with some works proposing it is possible to use it on all the situations for whole-body scanning and not for small parts of the body (VITALI; RIZZI, 2018) also, some only endorse it for the apparel industry (BRAGANÇA et al., 2018; VITALI; RIZZI, 2018; SOILEAU et al., 2016). Likewise, some works found underestimation 


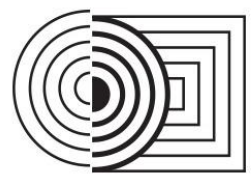

\section{$17^{\circ}$ ERGODESIGN \& USIHC 2019 \\ PUC-Rio, 11 a 13 de dezembro \\ Rio de Janeiro, RJ, Brasil}

$17^{\circ}$ Ergodesign - Congresso Internacional de Ergonomia e Usabilidade

de Interfaces Humano Tecnológica: Produto, Informações Ambientes Construídos e Transporte

$17^{\circ}$ USIHC - Congresso Internacional de Ergonomia e Usabilidade

de Interfaces Humano Computador

of measures (ALAVANI; KAMAT, 2015) and some overestimations (CLARKSON et al., 2014), overall, they found errors of less than $0,5 \mathrm{~mm}$. We can consider that knowing this limitation, the equipment can be used for well-thought-out situations. Also, it is central to notice the low-cost aspect is beneficial for applications that have cost constraints (GLEASON et al., 2018;

TARABINI et al., 2018; VITALI; RIZZI, 2018).

The other variable in this study is the subject's capability of holding the position for the necessary fixed time (SCHWARZ-MUELLER; MARSHALL; SUMMERSKILL, 2018). Even for young adults with full-body capabilities, holding a posture for more than 5 minutes is painful and uncomfortable (KEE; KARWOWSKI, 2001). When considering the possible participation of older persons, young children and persons with disabilities, this is yet more present (BUSSELL; MICHAUD, 1981). If we add to that the fact that a great part of scanning studies tends to turn the subject (CUI; STRICKER, 2011) instead of the equipment, the holding posture capability decreases because it is adding equilibrium to the mix (SCHWARZ-MUELLER; MARSHALL; SUMMERSKILL, 2018). In our study, we eliminated this factor developing a platform that keeps the subjects stable and moves the sensors around them. Another point regarding time is that there might be a relation between scanning time and the quality of the mesh. Shorter scanning times tend to leave holes and blank spaces that add to the post-processing time of the digital model (HEYMSFIELD et al., 2018; SHU et al., 2013). The ideal time is such that the participants are comfortable enough that they can hold the posture for the determined time and that the scan is as complete as possible.

ISO 7250 (2017) proposes some postures which can be used to take the digital measurements. Nonetheless, these postures aren't always compatible with the 3D scanning considering that when the arms are pressed to the side of the body, they are joined with the body challenging the collection of measurements. ISO 20685-1 (2018) attempts to address that, but in doing so, some of the measurements were excluded. Some positions also change the whole body's posture (SCHWARZ-MUELLER; MARSHALL; SUMMERSKILL, 2018) and body part sizes (CHOI; ASHDOWN, 2011) so they need to be selected carefully. Finally, some postures are more uncomfortable than others (KEE; KARWOWSKI, 2001) because they request fight against gravity and can only be held for shorter periods, others still are impossible to hold depending on the participant's pathologies and disabilities.

Considering this context, we hypothesized that in using low-cost scanners, the principal influences on the quality of the mesh are the postures adopted by the participants and the scanning time which affects their capability of holding the posture. To test our hypothesis, we devised an experiment to determine the best postures, considering the norms, the limitations of the low-cost equipment, the quality of the mesh obtained, the time taken to do the scans, the ergonomic analyses of the postures, the participant comfort and our scanning hardware. The final objective was to improve our protocol for large-scale anthropometric studies.

\section{METHOD}

This experiment was devised to evaluate different postures taken from the various norms and large-scale studies in terms of the capability of holding the posture by the participants in the required period, comfort rating after the posture was adopted and quality of the mesh obtained. The postures chosen were 6 arm positions merged into 3 postures taken from ISO (2018), ISO (2017) and Spahiu, Shehi and Piperi (2016), and can be seen in figure 1 (item 2.1). The time constraints were imposed by the time it took for the platform to be turned once or twice as shown in the experiment configuration (item 2.1). 
For the comfort analysis, we used Shackel's General Comfort Scale (SHACKEL; CHIDSEY; SHIPLEY, 1969) which is a rating scale of eleven points. The scale is the following: 1. I feel completely relaxed; 2 . I feel perfectly comfortable; 3 . I feel quite comfortable; 4 . I feel barely comfortable; 5 . I feel uncomfortable; 6 . I feel restless and fidgety; 7 . I feel cramped; 8. I feel stiff; 9. I feel numb; 10. I feel sore and tender; 11. I feel unbearable pain.

The posture's ergonomic assessment was made using REBA - Rapid Entire Body Analysis (HIGNETT; MCATAMNEY, 1997), which provides a number from 1 to 11, which reflects the level of risk for the postures evaluated. They are divided into five as follows: 1 - negligible risk; between and 2 and 3 - low risk; between 4 and 7 - average risk; between 8 and 10 - high risk, should be modified; and 11 - very high risk, changes need to be implemented immediately. REBA analysis was made considering the participant holding the positions shown in Figure 1 for 3 minutes without heights.

The mesh was analyzed following the MAP - Mesh Analysis Protocol. created by the authors. that gives a numerical grade for the mesh obtained from 0 - unusable to 100 - optimal, it considers that a usable mesh has a grade between 40 and 100 and that a great mesh is from 80-100. It evaluates calibration errors, sewing errors (disagreement between the beginning and end of the mesh), holes, foreign objects, movement during scanning, software and hardware limitations, protrusions and reconstruction errors.

\subsection{Experiment configuration}

In figure 1 is an overview of the experiment configuration, with a representation of the scanning platform and postures evaluated.

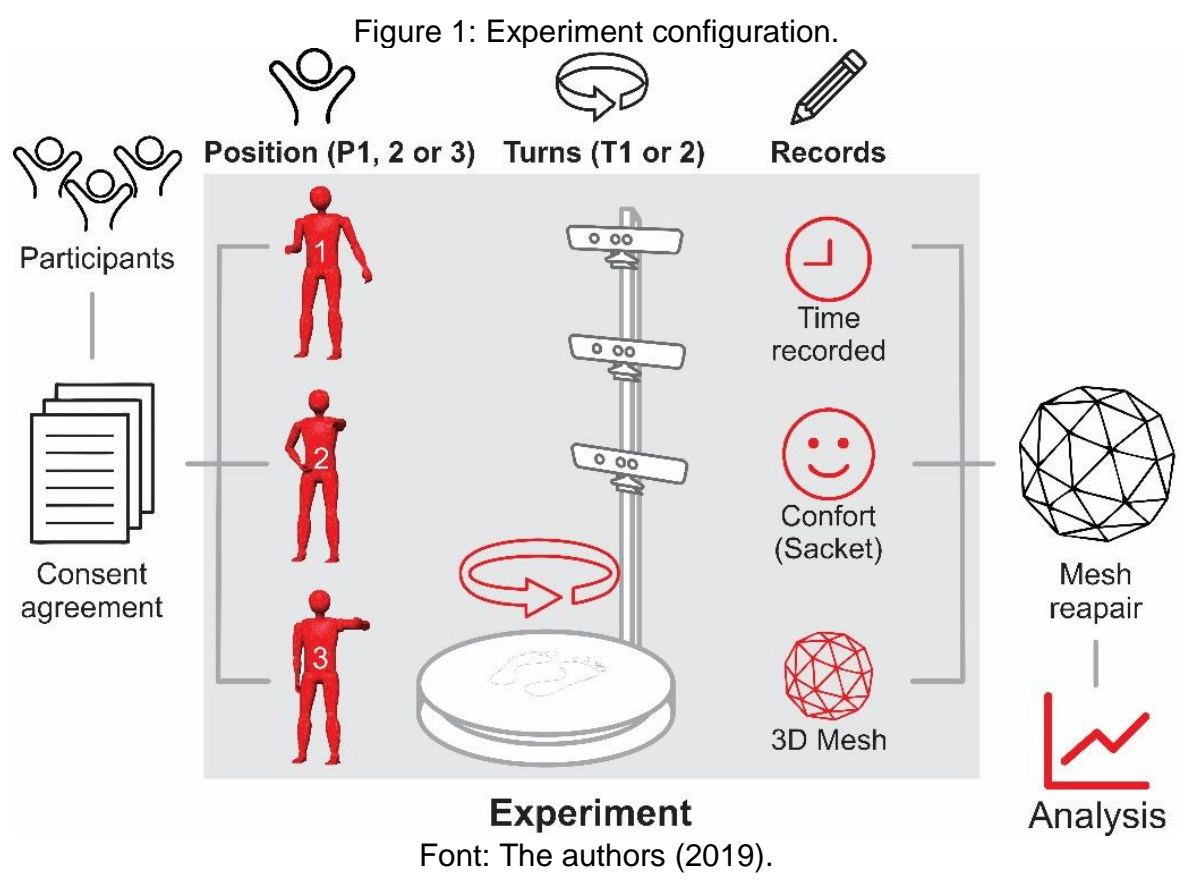

The experiment was the following, first, the participants were presented the tasks and were asked to sign consent agreements. After they signed, they were scanned three times, one in each posture in random order. The participant stood on the platform and the scanners were turned around them manually. The order of postures and number of turns was randomized to 


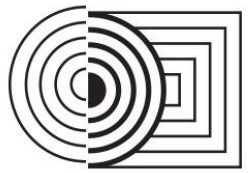

\section{$17^{\circ}$ ERGODESIGN \& USIHC 2019 \\ PUC-Rio, 11 a 13 de dezembro \\ Rio de Janeiro, RJ, Brasil}

$17^{\circ}$ Ergodesign - Congresso Internacional de Ergonomia e Usabilidade de Interfaces Humano Tecnológica: Produto, Informações Ambientes Construídos e Transporte

$17^{\circ}$ USIHC - Congresso Internacional de Ergonomia e Usabilidade

de Interfaces Humano Computador

avoid biases such as tiredness and learning. After each scan, the participants were asked to answer a comfort scale level (SHACKEL; CHIDSEY; SHIPLEY, 1969). After, we graded each scan using the MAP protocol and tabulated the times and comfort scales (SHACKEL; CHIDSEY; SHIPLEY, 1969). At the same time, we also did the REBA (HIGNETT; MCATAMNEY, 1997) analysis of the postures. Finally, the meshes were saved and repaired. As our objective was to analyze the postures and the experiment configuration itself, we did not retake any scan even if there were problems with the posture or the scanners, to permit the discussion on the comprehension of the postures and to catch the limitations of the scanning system.

\subsection{Materials}

The scanning platform used works with 3 Kinects 360 (MICROSOFT, 2019). The platform is constructed in metal bars and wood surfaces with 3D printed holders for the Kinects that can be height adjusted manually. The platform radius is one meter. The scanning software used was RecFusion (RECFUSION, 2019) and the mesh cleaner was Meshmixer (AUTODESK, 2019). For the working of the Kinects, an appropriate laptop with high processing power was used and for the registration of the participant, another standard laptop was used. On the day of the experiment were present five researchers that performed the different tasks of participant registration, scan control, data registration and platform work.

\subsection{Sample selection}

Our sampling strategy was using a convenience sample since the objective was to compare and choose scanning postures and not to do statistical inferences. Nonetheless, from the convenience sample we only invited to participate adults that were able-bodied and had no musculoskeletal complaints or diseases at the time of the experiment.

\section{EXPERIMENT DATA}

Next, we present the data for the sample characterization, mesh quality obtained using MAP, participant comfort (SHACKEL; CHIDSEY; SHIPLEY, 1969), posture analysis with REBA (HIGNETT; MCATAMNEY, 1997) and scanning times. And following we discuss the relations between posture, time, mesh quality and comfort; and final recommendations on posture and scanning protocol. The subjects are represented by 'S'(S1-S16), the postures by 'P' (P1, P2, P3 in the order presented in Figure 1) and the turn by T1 (one turn) and T2 (two turns).

\subsection{Sample characterization}

The sample was composed of sixteen participants ( 6 females and 10 males) (Table 1 ) from the convenience sample.

Table 1: Sample characterization.

\begin{tabular}{|l|c|c|c|}
\hline & Females $(\mathrm{n}=6)$ & Males $(\mathrm{n}=10)$ & Total $(\mathbf{n}=\mathbf{1 6})$ \\
\hline Height $(\mathrm{cm})$ & $159,8 \pm 4,9$ & $177,4 \pm 6,1$ & $\mathbf{1 7 0 , 8} \mathbf{1 0 , 2}$ \\
\hline Weight $(\mathrm{kg})$ & $69,3 \pm 12,6$ & $82,2 \pm 10,7$ & $\mathbf{7 7 , 3} \pm \mathbf{1 3 , 1}$ \\
\hline
\end{tabular}

They all signed consent agreements to participate in the experiment. Their ages varied from 24 
to 60 and were all able-bodied with no medical constraints that hindered their ability to hold the postures asked. In total, we took 48 scans (three for each participant).

\subsection{Mesh quality}

Using the MAP protocol, it was possible to grade all the meshes obtained on the following possible errors: calibration, sewing errors, holes, foreign objects, movement during scanning, software and hardware limitations, protrusions and reconstruction errors. The final MAP scores (graphic 1) varied from 38,1 (outlier) to 89,5 staying above the recommended line, except S6 with two turns that had a grade of 38,1 and can be considered unusable.

Graphic 1: MAP scores for different postures.

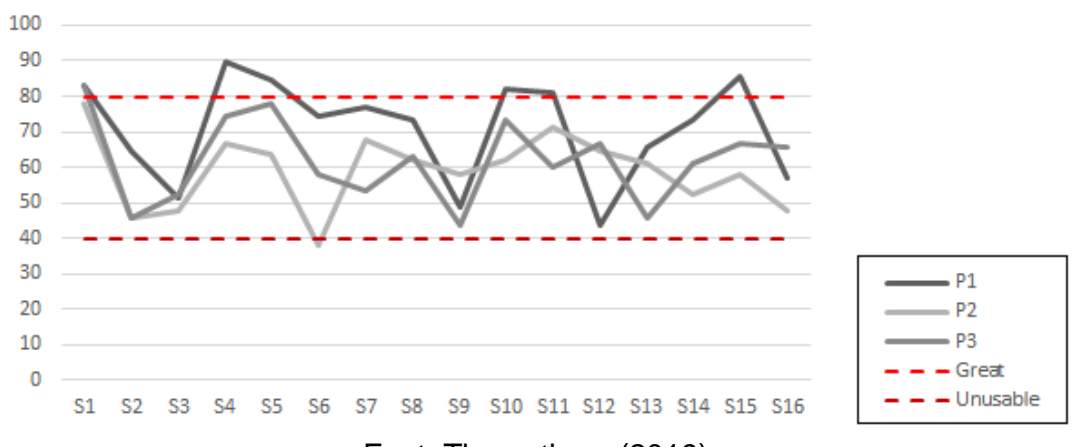

Font: The authors (2019).

Of the errors encountered, some were expected because we did not limit the clothing the participants used and some folds alter the quality of the scans. In special, we could perceive that besides the quality of the mesh and limitations of the participants, some postural errors contributed to the poor quality of the mesh (Figure 2).

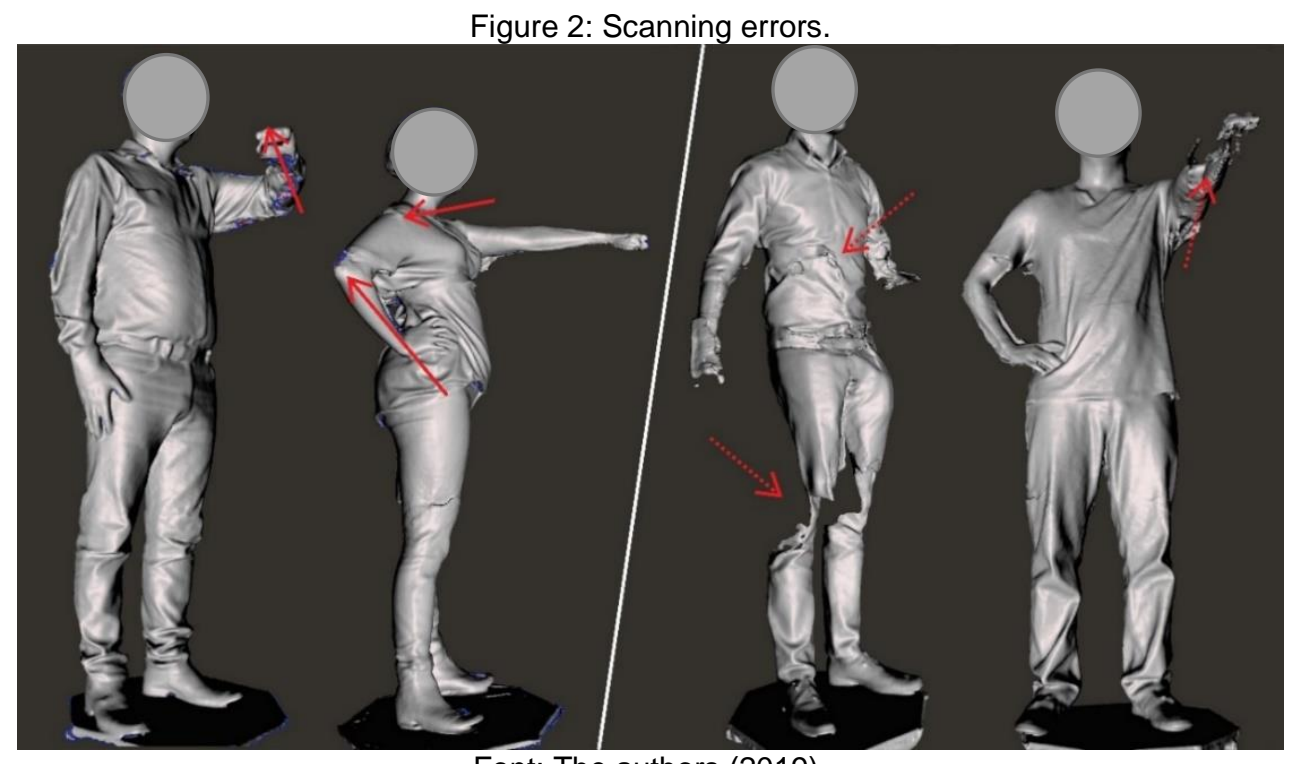

Font: The authors (2019).

In figure 2 it is possible to see some of the errors encountered. The two subjects on the left of figure 2 are postural errors and on the right scanning/calibration errors. Some postures, with 
folded arms, changed the whole body's position. Also, the distance limitations of the platform and the different height of the subjects affected the quality of the scanning, especially with the extended arms. Likewise, the calibration went off for two of the participants. The differences between the mesh scores for posture and number of turns are in table 2.

Table 2: Average MAP scores for different postures and the number of turns.

\begin{tabular}{|c|c|c|c|}
\hline & T1 & T2 & $\overline{\mathbf{x}}$ \\
\hline P1 & 71,9 & 69,6 & $\mathbf{7 0 , 7}$ \\
\hline P2 & 59,4 & 58,7 & $\mathbf{5 9 , 0}$ \\
\hline P3 & 56,7 & 67,1 & $\mathbf{6 1 , 9}$ \\
\hline$\overline{\mathbf{X}}$ & $\mathbf{6 2 , 7}$ & $\mathbf{6 5 , 1}$ & \\
\hline
\end{tabular}

Font: The authors (2019).

As it is seen, the postures influenced more the quality of the mesh than the number of turns which gave similar MAP results. This may be because of the limitations of the equipment.

\subsection{Participant comfort}

For the participant comfort, the averages were similar (table 4 and 5) staying, in the middle of the comfort scale (SHACKEL; CHIDSEY; SHIPLEY, 1969), in this case, the lowest score is preferable. They were: 4 . I feel barely comfortable; 5 . I feel uncomfortable; 6 . I feel restless and fidgety.

Table 4: Comfort with one turn.

\begin{tabular}{|c|c|c|c|c|c|c|c|c|c|c|c|c|c|c|c|c|c|}
\hline & S1 & S2 & S3 & S4 & S5 & S6 & S7 & S8 & S9 & S10 & $\mathrm{S} 11$ & $\mathrm{~S} 12$ & $\mathrm{~S} 13$ & S14 & S15 & S16 & $\bar{x}$ \\
\hline $\mathrm{P} 1$ & 5 & 4 & & & 4 & 1 & 4 & & & & 3 & 4 & 2 & 4 & & & 5,2 \\
\hline P2 & & & 4 & 9 & 5 & & & & 3 & 10 & 6 & & & & 9 & 3 & 6,2 \\
\hline P3 & 10 & 5 & 5 & & & & 5 & 5 & 5 & & & & 4 & & 5 & & 5,5 \\
\hline
\end{tabular}

Font: The authors (2019).

Table 5: Comfort with two turns.

\begin{tabular}{|c|c|c|c|c|c|c|c|c|c|c|c|c|c|c|c|c|c|}
\hline & S1 & S2 & S3 & S4 & S5 & S6 & S7 & S8 & S9 & S10 & S11 & S12 & S13 & S14 & S15 & S16 & $\overline{\mathbf{x}}$ \\
\hline P1 & & & 4 & 6 & & & & 4 & 3 & 5 & & & & & 3 & 6 & $\mathbf{4 , 5}$ \\
\hline P2 & 9 & 5 & & & & 5 & 5 & 5 & & & & 9 & 8 & 6 & & & $\mathbf{6 , 5}$ \\
\hline P3 & & & & 10 & 5 & 5 & & & & 10 & 7 & 5 & & 6 & & 4 & $\mathbf{6 , 5}$ \\
\hline
\end{tabular}

Font: The authors (2019).

The most comfortable posture was posture 1, and the least comfortable posture 2. Participants S1, S4 and S9 were responsible for the highest grades, seemingly independent from the posture or the number of turns which leads us to believe that they were already in some kind of pain or muscular distress before the scanning. The number of turns appears to not influence on the difference between the discomfort scale averages.

\subsection{Ergonomic assessment}

As for the comfort scale, lower scores in the REBA (HIGNETT; MCATAMNEY, 1997) analysis are also preferable and were encountered on the postures selected. They were all considered low-risk postures and were for P1 two points and P2 and P3 three points. The low scores are related to the low time expected of the participants to hold the posture, the lack of vibration and weights to hold, the neutral position of the legs and upright posture of the torso. The principal ergonomic concern is the position of the arms extended in the front and side of the body. 


\subsection{Scanning time}

The time differences between the scans taken with one turn and with two turns (table 6) were not proportional and averaged 66s for one turn and 94s with two turns.

Table 6. Average time for one and two turns.

\begin{tabular}{|c|c|c|c|c|}
\hline & P1 & P2 & P3 & $\bar{x}$ \\
\hline T1 & 67,5 & 65,8 & 66,7 & 66,7 \\
\hline T2 & 93,8 & 97,4 & 91,9 & 94,4 \\
\hline \multicolumn{5}{|c|}{ 에: The authors (2019). }
\end{tabular}

This difference might be because the first turn is the one responsible for collecting the geometry and the second is for smoothing the mesh and for collection of parts that might have been missed on the first turn and as such is a faster process. Nonetheless, because of the participant's involuntary movement, in the second turn, some of the posture errors might compound leaving the mesh with more errors than before.

\section{DISCUSSION}

Before outlining the preferred posture and scanning protocol, there are some reflections to be made on the results considering, the relations between posture, time, mesh quality and comfort that are outlined and discussed below.

There seems to be a greater influence of the posture on the mesh quality than time in mesh quality. Even though the time with two turns of the platform was $40 \%$ greater, the increase in mesh quality did not justify the extended period, improving only 2.5 points. This leads us to believe that the mesh problems were related to the limitations of the equipment and the posture selected other than the time the participant held the posture.

The first posture with one of the arms slightly suspended and the other bent in the standard manual anthropometric measurement position, gave the best mesh quality, firstly because it was not touching the body and did not weld the area and secondly because it is an easier posture to hold for the specified period. The worst posture, the second, with one of the arms extended and the other bent at the waist, gave the worst mesh quality, because of the difficulty of holding the arm extended in the front of the body, making it sway, and hindering the closing of the mesh. Also, for people with arm length greater than the maximum size of the platform, part of the arms and the head, were not possible to scan leaving an open hole.

If an exact posture is necessary for the experiment, the researchers must guide the user to act the exact posture, producing visual cues for them to follow, adding handlebars and/or even adding a mirror so the participants can check themselves and autocorrect their posture. The mirror should be placed directly in front of the subject, so they do not need to change head position for looking at themselves.

The other problem with the mesh quality was the calibration which hindered the quality of some scans. This could have been corrected at the time but we opted not to do so to demonstrate that this can occur. For actual anthropometric studies, this problem can be avoided, or corrected, with the recalibration of the scanners every so often. If it goes off for one participant their scan can be remade for with the correct calibration. In this context, the MAP score can be used to determine whether the scan should be remade or not according to the score given.

The participant's comfort, as predicted, was influential on the quality of the scans. Some, even with reporting of having no preconditions that could deter them from holding the position 
had difficulty and reported great levels of discomfort. This was not related to age and was probably a cause of some musculoskeletal distress from before the scans or overall lower pain threshold. If we extrapolate this for more specific populations such as elderly people and children this is an important question to note. Even if the posture is tolerable for most of the participants, some may not be able to hold it, and this might call for alternative positions. Also, there seems to be a disconnect between what is considered a low-risk posture and the discomfort of the participant. Even though they were marginally comfortable, the musculoskeletal risk is low for all the postures, probably because of the low amount of time that is required for holding the postures.

Most of the problems encountered can be corrected with the use of appropriate clothing, changes to the scanning platform such as variable lengths and heights for different participants and changes to the protocol, especially for the calibration of the scanners if working with more than one at a time. To expedite the process for a greater number of participants, they could be divided into height percentiles before the scanning and scanned into groups with appropriate platform lengths for the size of the participants.

\subsection{Final recommendations on posture and scanning protocol}

Finally, we were able to choose the best posture (figure 3) which was the one that gave the best mesh quality and that was also the most comfortable for the participants so they could hold it for more time.

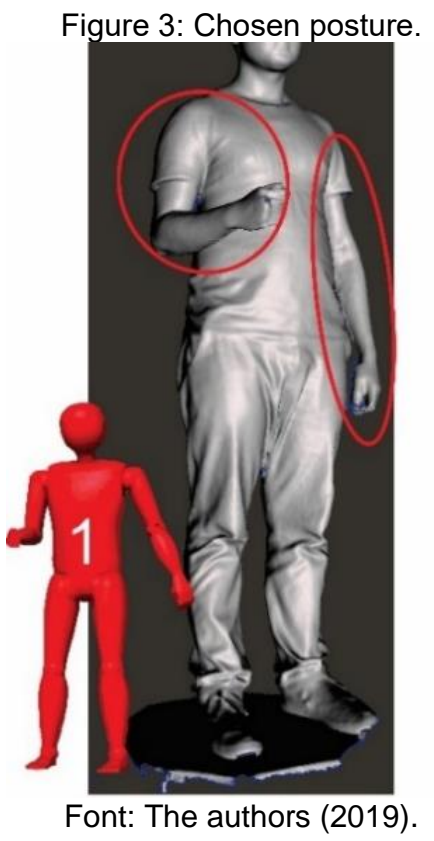

In addition to the posture, there are some other recommendations necessary to guarantee the quality of the scans, including fewer holes, less time and best participant comfort. These are: doing only one turn with the platform, the use of appropriate clothing, include high and length adjustments to the platform to better accommodate different percentiles, optimization of scanning with clustering the participants before scanning and system recalibration.

The choice of one turn is proposed based on the findings, the second turn did not add to the quality to the mesh, and the added time affected the capability of the participants to hold the 


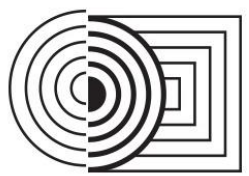

\section{$17^{\circ}$ ERGODESIGN \& USIHC 2019 \\ PUC-Rio, 11 a 13 de dezembro \\ Rio de Janeiro, RJ, Brasil}

$17^{\circ}$ Ergodesign - Congresso Internacional de Ergonomia e Usabilidade de Interfaces Humano Tecnológica: Produto, Informações Ambientes Construídos e Transporte

$17^{\circ}$ USIHC - Congresso Internacional de Ergonomia e Usabilidade

de Interfaces Humano Computador

posture. The clothing additionally affects the scanning and collection of measurements and morphology. The folds are potential holes and incorrect geometry that will need to be cleaned afterward. The appropriate clothing is, if possible, minimal clothing such as underwear or beachwear, and tied hair. If not possible, the clothing should be closed fitting like gym wear.

The changes to the platform and clustering of the participants are specific to this experimental configuration, but these are necessary changes to ensure the correct capture of all the body of all participants. The equipment has distance constraints (the subject needs to be $50-60 \mathrm{~cm}$ from the scanner) so if the distance is too great the geometry will not be collected. If some of the subjects are too short, and some are too tall, the distance changes may affect the capability of getting the whole mesh and in this context, the platform needs to be adjustable.

Finally, the calibration recommendation came from the experience that every five or six participants some calibration errors occurred. If the scans are being done and no errors of such nature occur, this step can be ignored until needed. If the step is not taken, at least every five scans the mesh needs to be checked, using the MAP protocol, for example, to verify the need for recalibration.

\section{FINAL CONSIDERATIONS}

With this experiment, we discovered that the postures adopted had more influence on the quality of the mesh, then the time and the number of turns to do the scanning. This proved that our hypothesis was correct especially for the effect the posture had on the quality of the mesh. This experiment also helped us to improve our scanning protocol, with the principal changes and positions underlined on item 4.1.

Comfort, although being a subjective matter, was useful for discussing and choosing between the postures. Even for the small sample, there were conflicting results that would probably also be verified with greater samples. The other measures such as quality, ergonomic assessment and time were also effective in analyzing the data and easily collected.

Because of the variability added when dealing with different people, and because of the influence these people might be for the quality of the overall study they should always be carefully considered. Participant safety and well-being must be one of the first considerations when devising an experiment. This work, while answering our questions about our experiment conditions can also be a guideline for the preparation and verification of other experimental configurations in regards to subject participation.

3D scanning as an ergonomic product development tool has been arising as a viable, safe and fast option, and now is the time to consider its possibilities and limitations especially in regards to user-centered design even in the data collecting stage. When analyzing anthropometric and product development studies using 3D scanners, the posture and positions are often ignored and poorly described. New protocols considering users and their limitations need to be developed to make the use of this technology more viable and accessible.

\section{BIBLIOGRAPHIC REFERENCES}

ALAVANI, G. K.; KAMAT, V. Human face anthropometric measurements using consumer depth camera. In: NATIONAL CONFERENCE ON COMPUTER VISION, PATTERN RECOGNITION, IMAGE PROCESSING AND GRAPHICS, 5, 2015, Patna. Anais [...]. Patna: IEEE, 2015. p. 1-4. AUTODESK. Meshmixer 3.5. Disponível em: http://www.meshmixer.com/. Acesso em: 05 set. 2019. 


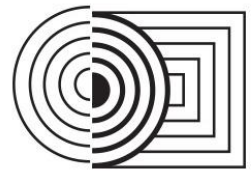

\section{$17^{\circ}$ ERGODESIGN \& USIHC 2019 \\ PUC-Rio, 11 a 13 de dezembro \\ Rio de Janeiro, RJ, Brasil}

$17^{\circ}$ Ergodesign - Congresso Internacional de Ergonomia e Usabilidade de Interfaces Humano Tecnológica: Produto, Informações Ambientes Construídos e Transporte

$17^{\circ}$ USIHC - Congresso Internacional de Ergonomia e Usabilidade

de Interfaces Humano Computador

BRAGANÇA, S. et al. Validation study of a Kinect based body imaging system. Work, v. 57, n. 1, p. 9-21, 2017.

BRAGANÇA, S. et al. A comparison of manual anthropometric measurements with Kinect-based scanned measurements in terms of precision and reliability. Work, v. 59, n. 3, p. 325-339, 2018. BRENDLER, C. F. et al. Uso da digitalização 3D do corpo humano para desenvolvimento de produtos personalizados: Análise comparativa entre os scanners Artec EVA e o Kinect.

Estudos em Design, v. 24, n. 2, p. 24-43, 2016.

BUSSELL, P.; MICHAUD, L. Seated anthropometry: The problems involved in a large-scale survey of disabled and elderly people. Ergonomics, v. 24, n. 11, p. 831-845, 1981.

CHOI, S.; ASHDOWN, S. P. 3D body scan analysis of dimensional change in lower body

measurements for active body positions. Textile Research Journal, v. 81, n. 1, p. 81-93, 2011. CLARKSON, S. et al. Assessing the suitability of the Microsoft Kinect for calculating person specific body segment parameters. In: EUROPEAN CONFERENCE ON COMPUTER VISION, 13, 2014, Zurich. Anais [...]. Zurich: Sringer, 2014. p. 372-385.

COSTA, T. N. et al. Uso da digitalização 3D e da parametrização de medidas antropométricas para produção de moldes personalizados para o vestuário. Educação gráfica, v. 19, n. 2, p. 122-142, 2015.

CUI, Y.; STRICKER, D. 3D body scanning with one Kinect. In: INTERNATIONAL CONFERENCE ON 3D BODY SCANNING TECHNOLOGIES, 2, 2011, Lugano. Anais [...]. Lugano: 3D Body.tech, 2011.

GARSTHAGEN, R. An open source, low-cost, multi camera full-body 3D scanner. In: INTERNATIONAL CONFERENCE ON 3D BODY SCANNING TECHNOLOGIES, 5, 2014, Lugano. Anais [...]. Lugano: 3D Body.tech, 2014.

GLEASON, J. R. et al. A safe, low-cost, easy-to-use 3D camera platform to assess risk of obstructed labor due to cephalopelvic disproportion. PloS one, v. 13, n. 9, p. e0203865, 2018. GUIDI, G.; GONIZZI, S.; MICOLI L. 3D capturing performances of low-cost range sensors for mass-market applications. In: INTERNATIONAL ARCHIVES OF THE PHOTOGRAMMETRY, REMOTE SENSING AND SPATIAL INFORMATION SCIENCES, 23, 2016, Prague. Anais [...]. Prague: XXIII ISPRS Congress, 2016, p. 33-40.

HEYMSFIELD, S. B. et al. Digital anthropometry: a critical review. European journal of clinical nutrition, v. 72, n. 5, p. 680-687, 2018.

HIRSHBERG, D. A. et al. Evaluating the automated alignment of 3D human body scans. In: INTERNATIONAL CONFERENCE ON 3D BODY SCANNING TECHNOLOGIES, 2, 2011, Lugano. Anais [...]. Lugano: 3D Body.tech, 2011. p. 5101.

ISO. ISO 7250-1: Basic human body measurements for technological design - Part 1: Body measurement definitions and landmarks. International Organization for Standardization, Geneva, Switzerland, 2017.

ISO. ISO 20685-1: 3-D scanning methodologies for internationally compatible anthropometric databases - Part 1: Evaluation protocol for body dimensions extracted from 3-D body scans. International Organization for Standardization, Geneva, Switzerland, 2018.

KEE, D.; KARWOWSKI, W. The boundaries for joint angles of isocomfort for sitting and standing males based on perceived comfort of static joint postures. Ergonomics, v. 44, n. 6, p. 614-648, 2001.

$\mathrm{KOUCHI}, \mathrm{M}$. et al. A protocol for evaluating the accuracy of 3D body scanners. Work, v. 41, n. Supplement 1, p. 4010-4017, 2012.

HIGNETT, S.; MCATAMNEY, L. Rapid Entire Body Assessment (REBA). Applied Ergonomics, v. 31, p. 201-205, 2000. 
MICROSOFT. Kinect 360. Disponível em: https://support.xbox.com/pt-BR/browse/xbox-360. Acesso em: 05 set. 2019.

PARK, B.-K.; REED, M. P. Rapid generation of custom avatars using depth cameras. In: INTERNATIONAL CONFERENCE ON 3D BODY SCANNING TECHNOLOGIES, 3, 2014, Lugano. Anais [...]. Lugano: 3D Body.tech, 2014.

RECFUSION. RecFusion 1.4.6. Disponível em: https://www.recfusion.net/index.php/en/. Acesso em: 05 set. 2019.

SCHWARZ-MUELLER, F.; MARSHALL, R.; SUMMERSKILL, S. Development of a positioning aid to reduce postural variability and errors in 3D whole body scan measurements. Applied ergonomics, v. 68, p. 90-100, 2018.

SHACKEL, B.; CHIDSEY, K. D.; SHIPLEY, Pat. The assessment of chair comfort. Ergonomics, v. 12, n. 2, p. 269-306, 1969.

SHU, C. et al. From 3-D Scans to Design Tools. In: INTERNATIONAL CONFERENCE ON 3D BODY SCANNING TECHNOLOGIES, 4, 2013, Lugano. Anais [...]. Lugano: 3D Body.tech, 2013. p.151-156.

SILVA, F. P.; SALVALAIO, C. L.; KINDLEIN, J. W. Análise Comparativa de Processos de Digitalização 3D para Modelos de Partes Humanas. In: CONGRESSO BRASILEIRO DE PESQUISA E DESENVOLVIMENTO EM DESIGN, 9, 2010, São Paulo. Anais [...]. São Paulo: Anhembi Morumbi, 2010.

SOILEAU, L. et al. Automated anthropometric phenotyping with novel Kinect-based threedimensional imaging method: comparison with a reference laser imaging system. European journal of clinical nutrition, v. 70, n. 4, p. 475, 2016.

SPAHIU, T.; SHEHI, E.; PIPERI, E. An Attempt for Developing Albanian Anthropometric System within a Pilot Project. In: INTERNATIONAL CONFERENCE ON 3D BODY SCANNING TECHNOLOGIES, 7, 2016, Lugano. Anais [...]. Lugano: 3D Body.tech, 2016. p.269-278.

TARABINI, M. et al. A prototype for the automatic measurement of the hand dimensions using the Microsoft Kinect V2. In: INTERNATIONAL SYMPOSIUM ON MEDICAL MEASUREMENTS AND APPLICATIONS, 2018, Roma. Anais [...]. Roma: MEMEA, 2018. p. 1-6. VERWULGEN, S. et al. A new data structure and workflow for using 3D anthropometry in the design of wearable products. International Journal of Industrial Ergonomics, v. 64, p. 108117, 2018.

VITALI, A.; RIZZI, C. Acquisition of customer's tailor measurements for 3D clothing design using virtual reality devices. Virtual and Physical Prototyping, v. 13, n. 3, p. 131-145, 2018.

\section{ACKNOWLEDGMENTS}

This study was financed in part by the Coordenação de Aperfeiçoamento de Pessoal de Nível Superior - Brazil (CAPES) - Finance Code 001. 